\title{
Ex vivo biomechanical analysis of two methods of osteosynthesis in canine mandibular fractures
}

\author{
Análise biomecânica ex vivo de dois métodos de osteossíntese em \\ fraturas mandibulares de cães
}

\author{
Luciano Jose Eigio Isaka ${ }^{1 *}$; Antonia Maria do Rocio Binder do Prado ${ }^{2}$; \\ José Ademar Villanova Junior ${ }^{3}$; Cláudia Turra Pimpão ${ }^{3}$; Paulo César Soares Júnior ${ }^{4}$
}

\begin{abstract}
Mandibular fractures represent an orthopedic challenge in veterinary medicine consideringthe large number of fixation methods that could be used depending on the location and manner in which the fracture occurs. Bone plates are a method of internal fixation that allows the correction of single or bilateral fractures, simple or comminuted; which appropriate material and technical knowledge for their use. Recent studies have demonstrated the superior strength that the locked plates present in relation to the neutralization plates, especially when used in flat bones or with lower bone density. The present study aimed to evaluate the biomechanical strength of neutralization plates and locked plates in oblique mandibular fractures in dogs. Sixteen hemimandibles from mesocephalic dogs were selected, weighing between 15 and $25 \mathrm{~kg}$, without mandibular pathological alterations. Unfavorable fractures were performed between the 2nd and 3rd premolar teeth. The hemimandibles were allocated to two groups and stabilized with neutralization (Group 1) and locked (Group 2) plates. Both groups were subjected to the vertical compression test using the EMIC DL500 machine, sought to note the difference of maximum resistance between the implants. The statistical analysis used was the $t$-test and showed no difference $(\mathrm{P}=0.135)$ between the strength of the group receiving neutralization plates $(21.08 \pm 9.766 \mathrm{kgf})$ and the group that received locked plates $(25.96 \pm 7.029 \mathrm{kgf})$. From the point of view of resistance to vertical compression, the neutralized and locked plates have the same biomechanical strength.
\end{abstract}

Key words: Mandibular fracture. Locked plates. Compression plates. Biomechanics.

\section{Resumo}

As fraturas mandibulares representam um desafio ortopédico na medicina veterinária, pois existe uma grande quantidade de métodos de fixação que podem ser utilizados dependendo do local e forma com que a fratura ocorre. As placas ósseas são um método de fixação interna que permite a correção de fraturas uni ou bilaterais, simples ou cominutivas, porém necessitam de material apropriado e conhecimento técnico para sua utilização. Estudos recentes têm demonstrado a resistência superior que as placas bloqueadas apresentam sobre as placas de neutralização, principalmente quando utilizadas em ossos chatos ou com menor densidade óssea. O presente estudo teve como objetivo avaliar a resistência biomecânica de placas de neutralização e placas bloqueadas em fraturas mandibulares oblíquas em cães. Foram selecionadas 16 hemimandíbulas de cães mesocefálicos, com peso entre 15 e $25 \mathrm{~kg}$ que não

\footnotetext{
${ }^{1}$ Discente de Doutorado, Programa de Pós-graduação em Ciência Animal, Pontifícia Universidade Católica do Paraná, PUCPR, Curitiba, PR, Brasil. E-mail: luciano.isaka@gmail.com

2 Prof., Curso de Medicina Veterinária, PUCPR, Curitiba, PR, Brasil. E-mail: marychello@hotmail.com

${ }^{3}$ Profs., Programa de Pós-Graduação em Ciência Animal, PUCPR, Curitiba, PR, Brasil. E-mail: jose.villanova@pucpr.br; claudia. pimpao@pucpr.br

${ }^{4}$ Prof., Programa de Pós-Graduação em Engenharia Mecânica, Pontifícia PUCPR, Curitiba, PR, Brasil. E-mail: pa.soares@pucpr.br

${ }^{*}$ Author for correspondence
} 
apresentavam alterações patológicas mandibulares. Fraturas desfavoráveis foram realizadas entre o $2^{\circ}$ e o $3^{\circ}$ dentes pré-molar. As hemimandibulas foram alocadas em dois grupos e estabilizadas com placas de neutralização (Grupo 1) e placas bloqueadas (Grupo 2). Ambos os grupos foram submetidos ao teste de compressão vertical realizado pela máquina EMIC DL500 no qual se buscou notar a diferença de resistência máxima entre os implantes. A análise estatística utilizada foi o teste $\mathrm{T}$ e demonstrou que não houve diferença $(\mathrm{P}=0,135799)$ entre a resistência do grupo que recebeu placas de neutralização $(21,08 \pm 9,766 \mathrm{kgf})$ quando comparado ao grupo que recebeu placas bloqueadas $(25,96 \pm 7,029 \mathrm{kgf})$. Do ponto de vista de resistência à compressão vertical as placas de neutralização e bloqueadas apresentam a mesma resistência biomecânica.

Palavras-chave: Fratura mandibular. Placas bloqueadas. Placas compressivas. Biomecânica.

\section{Introduction}

The mandibular fractures correspond to about $3 \%$ to $6 \%$ of all fractures occurring in dogs (LOPES et al., 2005). Typically, the region between the first premolar and the second molar is the most affected (KITSHOFF et al., 2013). Among the main causes are cranial traumas, auto accidents, neoplasia, chronic periodontal diseases, fights, and falls (LEGENDRE, 2005).

The mandible is the only movable bone of the skull and its main functions are the seizing and chewing of food (DYCE et al., 2010).

For the correct stabilization of a mandibular fracture, biomechanical factors such as forces originating from the masticatory muscles, direction of the fracture line, and forces involved in the development of the lesion should be considered (JOHNSON, 2014).

Currently,several of methodsare available for stabilizing mandibular fractures. Among the most common are the external fixator, cerclage and interdental acrylic resin, mandibular cerclage, use of compression screws, bone plates, and muzzleshaped splints (PIERMATTEI et al., 2009).

Bone plates provide adequate stability, rapid recovery of masticatory function, and can be used in single or bilateral fractures, simple or complex, and favorable or unfavorable.Since it is an internal fixation,this method causes minor inconvenience to the owner and discomfort to the patient (PIERMATTEI et al., 2009). Nevertheless, its positioning in the fracture requires a great detachment of soft tissues, and poses risk of injury to the dental roots and the vascularization and innervation present in the mandibular canal (JOHNSON, 2014). Currently, there are two types of bone plates, the neutralization/compression plates and the locked plates.

The stability of the neutralization plate occurs by the pressure that the screws exert on the plate and consequently on the cortical bone, mainly injuring the periosteal vascularization. The pressure on the cortical bone predisposes the formation of bacterial biofilms, which makes it impossible to use them at contaminated sites (HAALAND et al., 2009).

Locked plates are characterized by angular stability. The fixed interaction between the plate and the screws stabilizes the position of the screw irrespective of that of the implant, and a failure of the system only occurs if the whole system is released (FERRIGNO et al., 2007). The advantages of the locked system over the neutral system are the lack of lesion of the periosteal vascularization, the possibility of use at contaminated sites (HAALAND et al., 2009), and its greater resistance in flat, thin, or poor-quality bones (TAN; BALOGH, 2009).

The objective of this study was to compare the mechanical strength between neutralization and locked plates performed between the 2nd and $3 \mathrm{rd}$ premolars in transverse mandibular fractures in dogs. 


\section{Materials and Methods}

Eight mandibles without anatomical alterations of corpses of dogs weighing between 15 and $25 \mathrm{~kg}$ were collected. The causes of death were not related to diseases that could compromise the mandible.

Preparation of the mandibles involved the removal of all soft tissues, except the gingival mucosa. The mandibles were sectioned into hemimandibles by disjunction of the mandibular symphysis. Subsequently, osteotomies were performed, mimicking an unfavorable fracture, with the aid of a Dremmel circular saw, between the 3rd and 4th premolars at an angle of approximately 40 degrees.
Up to the day of the experiment, the hemimandibles were stored at $-60{ }^{\circ} \mathrm{C}$, and were thawed at room temperature 24 hours prior to the experiment and kept moistened with $0.9 \%$ saline solution to avoid desiccation.

The stabilization of the fractures was performed using 316L neutralization plates (Hexagon Industry and Trade in Orthopedic Implants Ltd., Brazil) (Figure 1) and 316L locked plates (Cao Médica Trade in Veterinary Surgery Material Ltd., Brazil) (Figure 2) positioned on the lateral border of the hemimandibles. Following the guidelines of the $\mathrm{AO}$ orthopedics, cortical screws fixed in a bicortical manner were used.

Figure 1. Stabilized dog mandible with a neutralization plate.

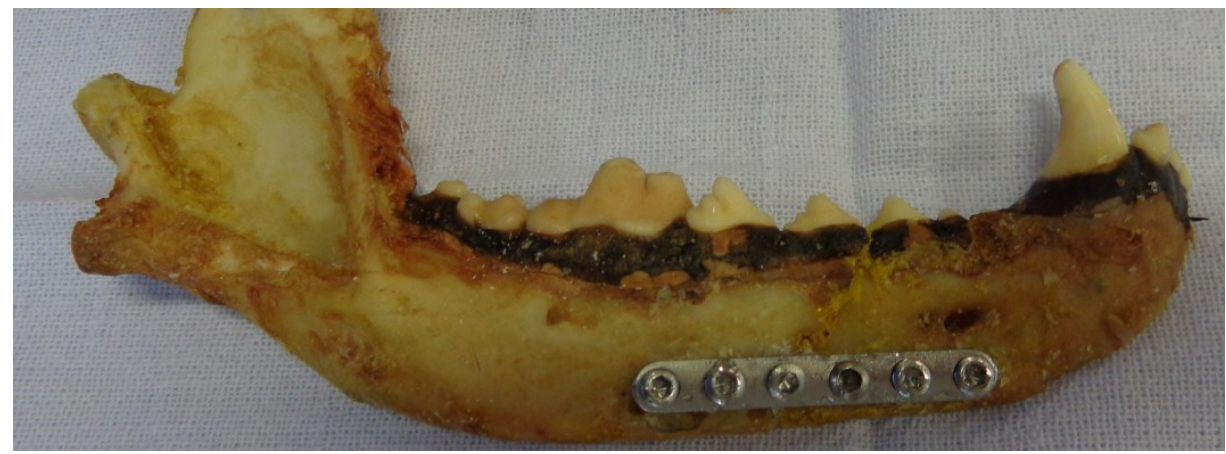

Figure 2. Locked plate positioned in the ventrolateral region of the canine hemimandible.

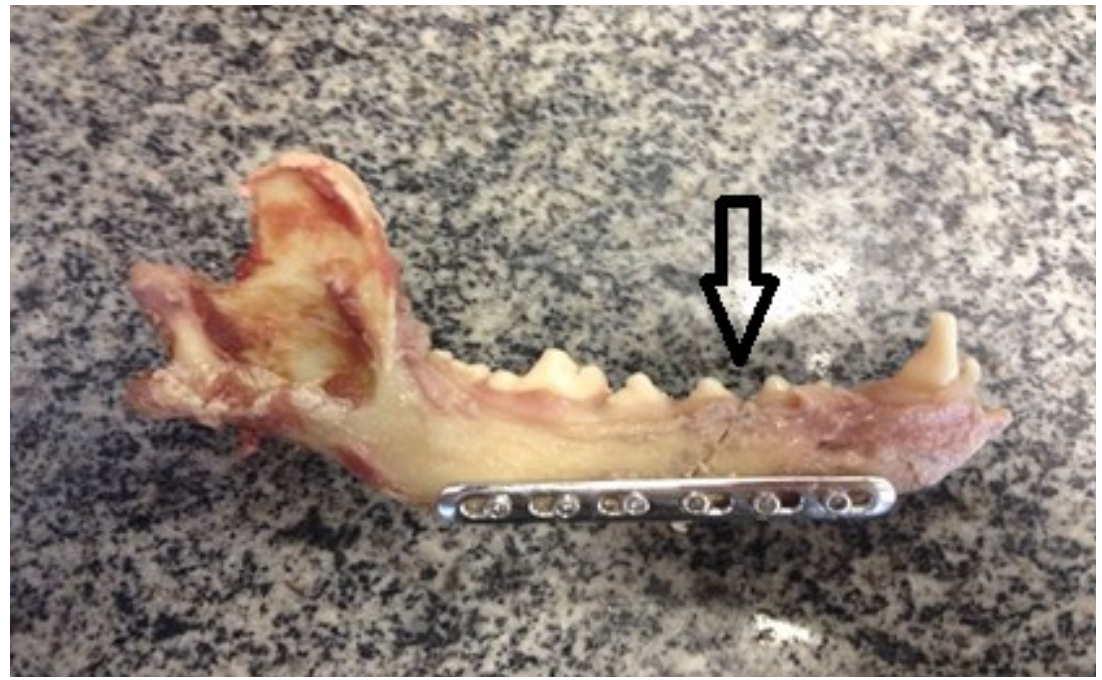


Hemimandibleswere divided into two groups: Group $1(\mathrm{n}=8)$ received stabilization with neutral plate $(45 \times 6 \times 1 \mathrm{~mm})$ and Group $2(\mathrm{n}=8)$ with locked plates $(70 \times 8 \times 2 \mathrm{~mm})$.In Group 1, fracture stabilization was performed with a $2.7-\mathrm{mm}$ six-hole plate, in which three rostral screws and three caudal screws were fixed in the fracture line, using cortical bone screws fixed in a bicortical manner. In Group 2, the fracture was stabilized using the same principles of Group 1; however,locked plates and screws were used. No fracture site compression was performed in any of the groups. Both groups were subjected to a force of $500 \mathrm{Kgf}$ at a speed of $20 \mathrm{~mm} / \mathrm{min}$.

The mechanical strength was tested with the aid of a universal test machine of the EMIC DL500 model from the Laboratory of Characterization and Destructive Testing of Materials of the Department of Mechanical Engineering of the Pontifical Catholic University of Paraná.A device developed by Lewicki (2012) was used to fix the anatomical parts during the tests. The mandibles were fixed with two steel screws positioned at the mandibular angle (Figure 3).After fixation of the hemimandible in the device, the set was submitted to the mechanical test, in which a force was applied with a velocity of $20 \mathrm{~mm} / \mathrm{min}$ on the incisor teeth until rupture of the implant and/or of the hemimandible (Figure 4). The applied force $(\mathrm{Kgf})$ and the deformation $(\mathrm{mm})$ of the hemimandiblewere recorded graphically until its rupture.

Figure 3. Device developed by Lewicki (2012) for fixation of mandibles during biomechanical tests.
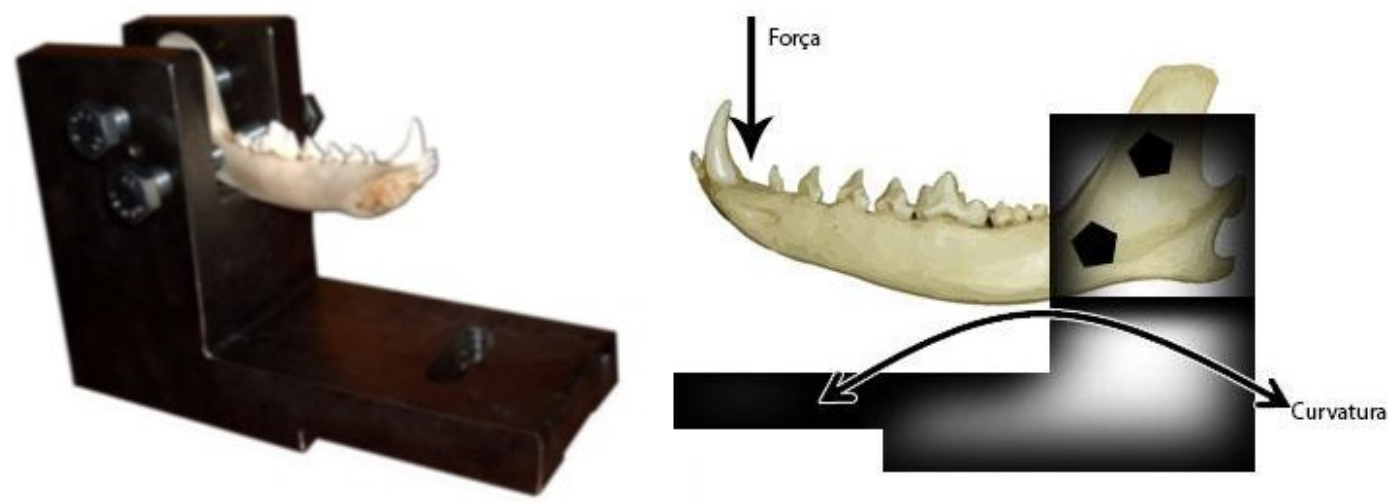

Figure 4. Dog hemimandible positioned for the biomechanical test. Note the force being applied to the incisor teeth.

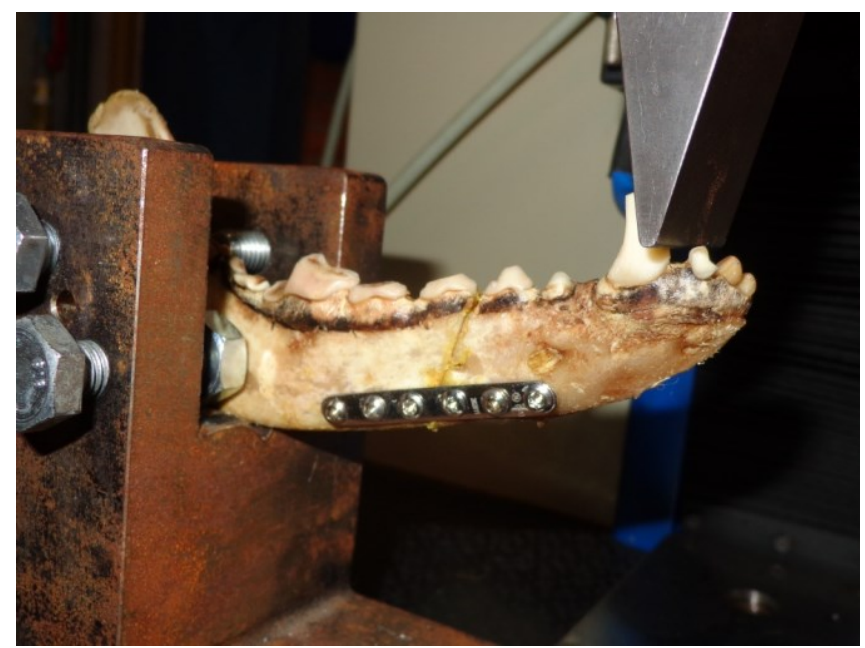




\section{Results and Discussion}

The statistical analysis used was Student's t-test, with significance level of $\mathrm{p} \leq 0.05$ for mechanical strength between compressionand locked plates.

Vertical tensile strength was $21.1 \pm 9.8 \mathrm{kgfin}$ Group 1 and 26.0 $\pm 7.0 \mathrm{kgf}$ in Group 2, with no significant difference $(\mathrm{P}=0.135)$. The deformation in Group $1(9.26 \pm 1.16 \mathrm{~mm})$ was lower than that in Group $2(10.77 \pm 1.35 \mathrm{~mm})$, but not statistically significant $(\mathrm{P}=0.414$; Table 1$)$.
In Group 1, loss of stability occurred due to bone fracture of the mandibular body in one part (12.5\%), avulsion of the 1 st caudal screw at the fracture line in two parts $(25 \%)$, and horizontal fissure in five parts (62.5\%;Figure 5).In Group 2, failure of the implants occurred through bone fissure of the caudal fragment at the fracture line in seven anatomical parts $(87.5 \%$; Figure 6$)$ and implant deformation in one part $(12.5 \%)$.

Table 1. Maximum and mean forces of the rupture of animals' hemimandibles belonging to Group 1 and Group 2.

\begin{tabular}{lccc}
\hline Group 1 & Maximum force (kgf) & Group 2 & Maximum force (kgf) \\
\hline Hemimandible 1 & 22.7 & Hemimandible 1 & 15.7 \\
Hemimandible 2 & 24.0 & Hemimandible 2 & 25.2 \\
Hemimandible 3 & 8.3 & Hemimandible 3 & 21.1 \\
Hemimandible 4 & 6.8 & Hemimandible 4 & 26.7 \\
Hemimandible 5 & 19.3 & Hemimandible 5 & 24.9 \\
Hemimandible 6 & 36.3 & Hemimandible 6 & 22.3 \\
Hemimandible 7 & 22.8 & Hemimandible 7 & 37.1 \\
Hemimandible 8 & 28.4 & Hemimandible 8 & 34.7 \\
\hline Mean & 21.1 & Mean & 26.0 \\
\hline Standard deviation & 9.8 & Standard deviation & 7.0 \\
\hline
\end{tabular}

Figure 5. Bone fissure (arrow) of the body of the dog hemimandible stabilized with neutralization plate.

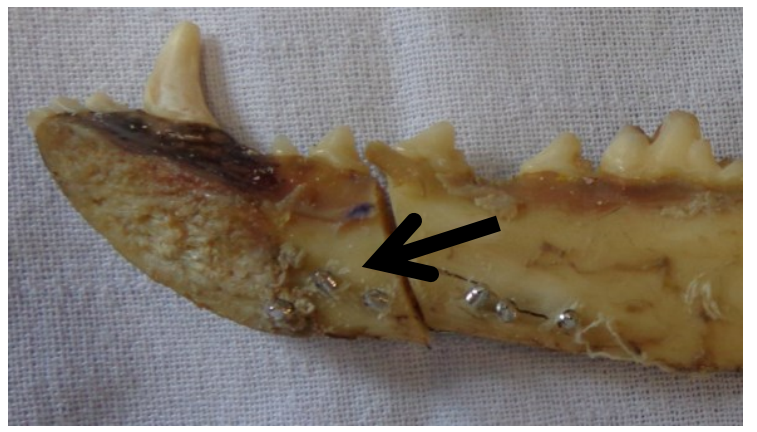

Figure 6. The image indicates the failure pattern occurred in Group 2 stabilized with locked plate. There was a fracture of the mandibular bone (arrow) in the caudal fragment at the fracture line.

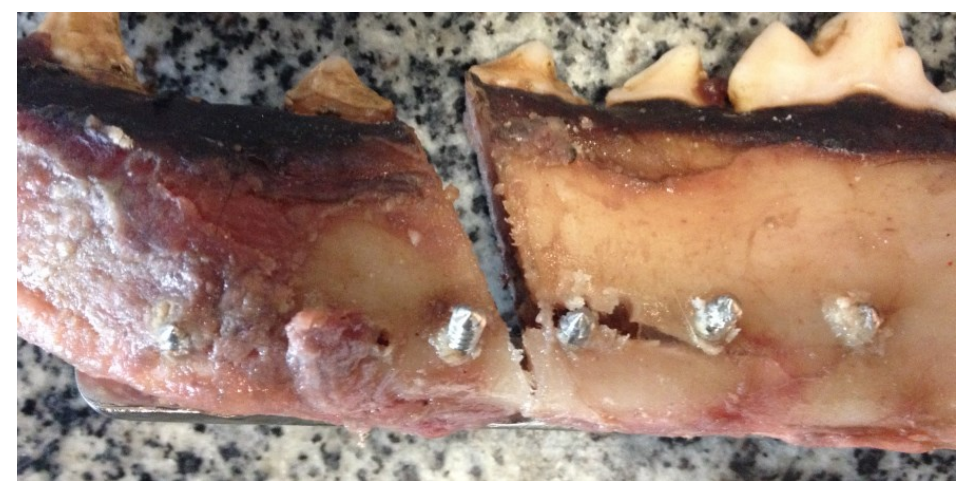


Several biomechanical tests to evaluate the maximum strength of implants in mandibular fractures have already been performed, and the hemimandibles were used in several previous reports (RAHAL et al., 1998;MILLER et al., 2011;LEWICKI,2012;ARZIet al., 2016). Evans (1973) and Ashman and Buskirk(1987) demonstrated that there are no differences in the biomechanical and bioelastic properties of frozen bones when they return to room temperature.

The results obtained in the comparison of mechanical strength between compressionand locked plates in the stabilization of fractures in the mandibular body were not statistically different. This is due to the fact that the main failure of the system occurred as a result of the fracture of the caudal bone fragment, demonstrating that the implants present greater fixation strength than the maximum strength of the mandibular bone.

In this study performed in the mandible body, the causes of loss of strength in the stabilization of Group 1 hemimandibles were bone fissures, followed by screw avulsion, and finally by complete bone fracture. These results are not in agreement with Miller et al. (2011) who compared the mechanical strength of compression and locked plates in the mandibular ramus of dogs and obtained the avulsion of the screws as the main cause of failure of the implant in the group of neutralization plates. According to Egol et al. (2004), the main cause of failure of the compression plates is the low pressure that the screws exert on the plate, leading to the migration of the screws fixed in the cortical bone. However, our present findings suggested that, although the mandibular body is a flat bone and presents little available bone tissue, the force generated by the screws, but not the avulsion of the screws, was enough to cause the bone fissure. Compared to the mandibular body, the mandible branch presents less bone tissue available for the fixation of the screws, which is probably the reason for the avulsion of the screws.
As observed in Group 1, the main cause of loss of strength in the stabilization of hemimandibles in Group 2 was bone fissure. This is in line with Miller et al. (2011) and Arzi et al. (2016) who observed that the stabilized group with locked plates had bone fissure as the main cause of stability failure. Tan and Balogh (2009) have reported that the angular stability provided by the locked plates only leads to destabilization if a complete or incomplete fracture (fissure) orbreakage of the plate or screws occurs. The bone fissure that occurred in the present experiment is due to the fact that the implants have greater resistance to mechanical compression than the mandibular bone itself.

Chiodoet al. (2006) compared the mechanical strength between locked plates and 2-mm compression plates, both with five holes, applied in bovine rib and submitted to flexion. They found no significant differences between the two stabilization methods, which is in line with our present findings. Thus, we suggest that, when placed under identical situations and with similar bone density, ribs and mandibles that are flat bones and with little bone availability might behave in a similar way.

Miller et al. (2011) compared the mechanical strength between compressive and locked plates in the mandibular ramus and found a mean resistance of $76.1 \mathrm{Kgf}$ for the locked plates and $48.31 \mathrm{Kgf}$ for the compression plates, demonstrating the superiority of the locked system for mandibular ramus fractures. The increased strength of the locked system in this situation is probably due to the poor bone availability of the mandibular ramus, according to Egolet al. (2004), who stated that the locked plates present greater fixation strength in sites with little bone availability.

Kitshoff et al. (2013) compared two methods of mandibular stabilization, namely stout loop and crossover methods, which use acrylic resin and interdental steel wire performed in hemimandibles with fractures between the 4th pre-molar and the 1 st molar. In the crossover method, the mean resistance 
was $8.6 \mathrm{Kgf}$, while it was5.6 Kgfin the stout loop method, demonstrating a low strength when compared to the plate and screw system.

Lewicki (2012) evaluated the resistance of dogs hemimandibles submitted to vertical traction, stabilized with acrylic resin associated with the interdental metal wire (stout loop method), compression plate, and external fixation; therecorded strengthswere $44.67 \mathrm{kgf}, 9 \mathrm{kgf}$, and $8.56 \mathrm{kgf}$, respectively. The results found by Lewicki in the use of acrylic resin associated with interdental metal wire differed from Kitshoffet al. (2013), which found a mean resistance of $8.6 \mathrm{Kgf}$ in the crossover method and $5.6 \mathrm{Kgf}$ in the stout loop method. This discrepancy is probably due to the amount of acrylic material used for the stabilization, which can be appreciated by examining the photos in both articles.

From a biomechanical point of view, the acrylic resin is the only stabilization method that can be used in the alveolar border, i.e. the ideal place for fixation. However, the low strength of the method is related to resin breakage or tooth surface resin detachment as found by Kitshoff et al. (2013). Nevertheless, Lewicki (2012) in his experiment used a large amount of resin and obtained strength of resistance greater than all other methods used, showing the importance of using the implant in the right location. When we compared the mean resistance of stabilization methods fixed in the lateral or ventrolateral region of the mandibular bone with fracture in the mandibular body, we noticed that the results do not exceed $26 \mathrm{Kgf}$ regardless of the size of the implant. Indeed, the main failure is the fracture of the mandibular bone in the fixation sites. The result found by Lewicki (2012), who used a large amount of acrylic resin on the alveolar border, thus preventing the implant break, shows the superior resistance of the region when compared to the other stabilization methods used in the ventrolateral border.

Using neutralization plates, Lewicki (2012) reported a strength of $9 \mathrm{kgf}$,in comparison with our present strength of $21.08 \mathrm{kgf}$. This discrepancy may be related to the fixation having been performed in a bicortical manner.

Rahal et al. (1998) compared the mechanical compressive strength of intact and osteotomized hemimandibles between the 2nd and 3rd premolars stabilized with interdental steel wire associated with dental acrylic resin and inter-fragmentary cerclage associated with acrylic resin. According to their findings, themean resistancewas $48.26 \mathrm{kgf}$ for intact mandibles, $15.9 \mathrm{kgf}$ for acrylic resin associated with interdental steel wire, and $3.38 \mathrm{kgf}$ for interfragmentary cerclage associated with acrylic resin. Both methods presented inferior strength when compared to the plate and screw. In this experiment, the authors found a value of $48.25 \mathrm{kgf}$ for intact hemimandibles, differing from the strength to intact hemimandible of $102 \mathrm{kgf}$ reported by Lewicki (2012). This difference suggests that the size of the animals interferes with their bone strength, since Rahal et al.(1998) used animals weighing up to 17 $\mathrm{kg}$, while Lewicki (2012) used animals weighing between 20 and $25 \mathrm{~kg}$.

The values found by Rahal et al. (1998), Lewicki (2012), and Arzi et al. (2016) for intact hemimandibles suggest that, although the plate and screw method has a higher compressive strength than other stabilization methods, post-operative care is still required, such as the use of liquid diets, feeding probes, and in some casesmuzzles, since no stabilization method can offer strength similar to strength of intact mandibles.

The larger size, length, and distance between the screws that the locked system presented were not sufficient to generate greater strength, showing that no materials with large dimensions are required in fractures in the mandible body. Nevertheless, since each fracture presents itself in a unique way, choosing the most appropriate stabilization method for each situation remains the task of the orthopedic surgeon. 


\section{Conclusion}

From a biomechanical point of view, there is no difference between the use of compressionandlocked plates in fractures involving the mandible body in dogs weighing between 15 and $25 \mathrm{~kg}$. However, in clinical practice, factors such as periodontal diseases, local contaminations, types of fracture, and economic aspects should be evaluated to determine the most appropriate methods to be applied.

\section{References}

ARZI, B.; STOVER, S. M.; GARCIA, T. C.; LEALE, D. M.; VERSTRAETE, F. J. M. Biomechanical evaluation of two plating configurations for critical sized defects of the mandible in dogs. American Journal of Veterinary Research, Chicago, v. 77, n. 5, p. 445-451, 2016.

ASHMAN, R. B.; BUSKIRK, W. C. The elastic properties of a human mandible. Advances in Dental Research, Dellas, v. 1, n. 1, p. 64-67, 1987.

CHIODO, T. A.; ZICARDI, V. B.; JANAL, M.; SABITINI, C. Failure strength of 2.0 locking versus 2.0 conventional synthes mandibular plates: a laboratory model. Journal of Oral and Maxillofacial Surgery, Newark, v. 64, n. 10, p. 1475-1479, 2006.

DYCE, K. M.; SACK, W. O.; WENSING, C. J. G. Tratado de anatomia veterinária. Rio de Janeiro: Elsevier, 2010. $840 \mathrm{p}$.

EGOL， K.; KUBIAK, E.; FULKERSON, E.; KUMMER, F. J.; KOVAL, K. J. Biomechanics of locked plates and screws. Journal of Orthopaedic Translation, New York, v. 18, n. 8, p. 488-493, 2004.

EVANS, F. G. Factors affecting the mechanical properties of bone. Bulletin of the New York Academy of Medicine, New York, v. 49, n. 9, p. 751-764, 1973.

FERRIGNO, C. R. A.; ITO, K. C.; ROMANO, L.; DELLANINA, M. I.; FERRAZ, V. C. M. Emprego clínico de placas ósseas bloqueadas em fraturas cominutivas de fêmur em cães. Primeiros relatos de utilização na ortopedia veterinária nacional. In: CONGRESSO BRASILEIRO DE VETERINARIA, 2007, Santos. [S.1.] : Santos, 2007. CD-ROOM.
HAALAND， P. J.; SSJOSTROM，L.; DEVOR, M.; HAUG, A. Appendicular fracture repair in dogs using the locking compression plate system: 47 cases. Veterinary and Comparative Orthopedics Traumatology, Oslo, v. 22, n. 4, p. 309-315, 2009.

JOHNSON, A. L. Tratamento de fraturas específicas. In: FOSSUM, T. W. (Ed.). Cirurgia de pequenos animais. Rio de Janeiro: Elsevier Mosby, 2014. p. 1106-1117.

KITSHOFF, A. M.; ROOSTER, H.; FERREIRA, S. M.; BURGUER, D.; STEENKAMP, G. The comparative biomechanics of the reinforced interdental crossover and the Stout loop composite splints for mandibular fracture repair in dogs. Veterinary and Comparative Orthopaedics and Traumatology, Pretoria, v. 26, n. 6, p. 461-468, 2013.

LEGENDRE, L. Maxillofacial fracture repairs. Veterinary Clinics of North America: Small Animal Practice, Vancouver, v. 35, n. 4, p. 985-1008, 2005.

LEWICKI, N. E. Avaliação biomecânica in vitro de osteossintese mandibular em cães.2012. Dissertação (Mestrado em Ciência Animal) - Escola de Veterinária, Pontifícia Universidade Católica do Paraná, São Jose dos Pinhais.

LOPES, F. M.; GIOSO, M. A.; FERRO, D. G.; LEONROMAN, M, A.; VENTURINI, M. A.; CORREA, H. L. Oral fractures in dogs of Brazil: a retrospective study. Journal of Veterinary Dentistry, São Paulo, v. 22, n. 2, p. 86-90, 2005.

MILLER, E. I.; ACQUAVIVA, A. E.; EISENMANN, D. J.; STONE, R. T.; KRAUS, K. H.Perpendicular pullout force of locking versus non-locking plates in thin cortical bone using a canine mandibular ramus model. VeterinarySurgery, Ames, v. 40, n. 7, p. 870-874, 2011.

PIERMATTEI, D. L.; FLO, G. L.; DECAMP, C. E. Fraturas e luxações da mandibula e maxila superior. Ortopedia e tratamento das fraturas dos pequenos animais. São Paulo: MANOLE, 2009. 896 p.

RAHAL, S. C.; FRANCISCONE, P. A.; IWABE, S.; SOARES, F. P. Métodos de fixação de fraturas mandibulares em cães: resistência mecânica a compressão. Ciência Rural, Santa Maria, v. 28, n. 3, p. 432-434, 1998.

TAN, S.; BALOGH, Z. Indications and limitations of locked plating. Injury, New Castle, v. 40, n. 7, p. 683691, 2009. 